\title{
Climate Establishment in an Ex-Indonesian International Standardized School
}

\author{
Cepi Safruddin Abdul Jabar \\ Jurusan Administrasi Pendidikan \\ Fakultas Ilmu Pendidikan, Universitas Negeri Yogyakarta \\ Yogyakarta, Indonesia \\ cepi_safruddin@uny.ac.id
}

\begin{abstract}
The success of the school in the academic side is embedded to the surrounding environment, especially how the relationship between the school communities in activities that binds them in a meaningful activity. A school-surrounding environment is impact of the interaction between individuals that are built in a planned concept of school climate. School climate are the external factors of motivation that determine the level of performance of the school community. On the other hand, it is a continuous school quality improvement effort. The research aim is to analyze School Principal efforts to build school environment that encourages community learning. This research employs qualitative-descriptive method. The subjects of this research are the school principal, teachers, and students. The main sources of information are the school principal, teachers, non-teaching staffs, and students. The data was collected through observation, interview, Focus Group Discussion, and documentation study. Data was processed by using descriptive data analysis techniques. The effort of principals in shaping the school environment that encourages community learning in school is a way to improve the quality of schools focusing all school components. There were some efforts made by principal in creating a school environment that encourages learning community.
\end{abstract}

Keywords-School climate; learning community;empowerment

\section{INTRODUCTION}

SMAN 1 Kasihan Bantul since 2009 was originally known as SMAN Tirtonirmolo. They switch from national standards into RSBI status (International Standardized School). This is a developing school, and slow but sure became a most popular school in the town. The school maintained families that interested to send their sons and daughters to SMAN 1 Kasihan because of the discipline. SMAN 1 Kasihan progress quite rapidly, student'sachievement was increasing, so the teachers were. The existence of a learning community grows in every corner of the school. It creates an ideal environment to the creation of many accomplishments

Schools have faced with lot of problems. School faced with policy problem, students achievement, low involvement of school community, government, quality of learning, low quality teachers, and so on. All problems that school faced as mentioned above are narrowed to the term of school quality itself. A way to improve the quality of education is through improved school climate. [1]. Both researchers proved that students could achieve better learning if they feel they are in a school climate favor. Likewise teachers, they may perform optimally when felt in the environment are preferred.

\section{RESEARCH OBJECTIVES}

With the above-mentioned situations and problem, the researcher got interested to study a research regarding school principal efforts to build school environment that encourages community learning in SMAN 1 KasihanBantul - Daerah Istimewa Yogyakarta - Indonesia.

\section{LITERATURE REVIEW}

School climate refers to the "taste" of the school, and this could vary from one school to another. School climate reflects the physical and psychological aspects of the school that is volatile and a necessary requirement for the best teaching and learning process. Long before that, the school climate defined as interpersonal relations, social, and cultural factors that influence behavior of individuals and groups in the school environment. [2] School environment can be interpreted in three dimensions. [3] First, the physical dimensions. It is about the appearance of school buildings and classrooms, the number of classrooms and the ratio of teachers and students, the classroom setting, as well as the availability of resources, and the safety and comfort. Second, social dimension. This dimension is comprised of the quality of interpersonal relationships between students, teachers and staff, fairness and equality from teachers to students and staff, the level of competition and social comparisons between students, schools and citizen involvement in decision-making. Third, academic dimension. This dimension describes the quality of learning, teacher expectations on student achievement, as well as the extent of the control / monitoring the schools to students' achievement.

Learning Community in the School Setting

The concept of learning community was inherent with popularity of changing global economic trends in the late 1980's that marked by the widespread availability of information and communication technologies. [4] Schools that adopt learning organization were characterized by the presence of synergy between staff, teachers and administrators in defining learning, curriculum, and collaborative work to improve the quality of teaching and learning process. Learning community or community of learning in the context of education builds a collaborative culture for teachers and students. [5] In the school context, they put the term learning 
community as fulfilling the needs of learning in a locality through partnerships among its members. Creating a shifting of culture in the perception of the value of learning required the strength of social relations and institutions. Thus the learning community is a way to encourage social cohesion in order to achieve organizational goals.

Learning community has two focuses. First that focuses on the human element and the benefits of synergy between individuals in the same place or interest as long they understand to each other and share the skills and knowledge. The second focus in the learning community is about the curricular structure, as a means to develop learning implicitly. In a learning community, knowledge is recognized as being owned by individuals and groups/ communities at the same time, which means that they share knowledge. According Leinhardt in Sergiovani, the notion of sharing knowledge is based on three assumptions. [6] The first assumption is that learning is an active process to build and feel of knowledge by students. The second assumption is that knowledge is an artefact of human culture; there is a process to create, deploy, and transforming as individuals or groups. Third, knowledge is distributed from one person to another in a single group. Shared knowledge would become greater and beneficial than when knowledge is only owned by one person. Referring to the explanation of the learning community, it can be concluded that it is strongly associated with learning theory and sociology. The concept of learning community is very appropriate to the circumstances in which the institutions are faced with an increasingly complex world that we cannot just rely on one or two people to acquire sufficient knowledge and skills.

Developing school climates it is mean that we must establish good communication between the school communities. There is a strong influence among the way a principal communicate with the school climate. [7] Climate was not only leading to the comfort and safety of the school environment and the behaviour of the students, but also students' relationships with their peers in learning, and learning management. Based on the various theories that have been studied, it can be concluded that the establishment of the school as a learning community requires support in the form of a positive climate. A positive school climate will encourage each member of the school to share and cooperate. It will make each of the school member want to learn, share knowledge, and gain experience with each other.

\section{RESEARCH METHODOLOGY}

The study employs qualitative-descriptive method. A qualitative approach was choses as the fit approach for the current study mainly because the study is exploratory in nature. The subjects of this research are the school principal, teachers, and students. The main sources of information are the school principal, teachers, non-teaching staffs, and students. The non-probability sampling method was used. In this sampling method, samples are chosen by researcher who represents the population. The themes that emerged from these participants are analyzed and tabulated for a clear understanding. Framework analysis was used to analyze gathered data. This method of analysis includes five phases, which are familiarizing, identifying a thematic framework, indexing, charting, mapping and interpreting.

a. Where did they start?

\section{FINDINGS}

The efforts of previous principal in improving school performance began with establishment the foundation of quality improvement in schools, a positive school climate. Although the position of Principal changed, the foundation has been quite solid as a basis for his/her successors to continue improving school quality. The first school reform plan document said that positive school climate was one of ultimate goal of the school reform must be achieved (Doc-1). It is mean that quality school improvement started with a positive school climate establishment

b. Capital for improving learning: Teachers

Learning improvement efforts conducted by the Principal at SMA 1 Kasihan is described as follows. "We refer to the curriculum, the ability of teacher competence stick on them ... we hope graduates increased. ... There are senior teacher and junior. Senior teacher is rarely able to keep up, but fortunately they are nearly bit the senior in this school, they are approaching retirement phase". (KS-4)

School principal considers that productivity can be seen on the school's performance the past few years as he said:

"I think the teachers are workaholic. No matter the time, in spite of Ramadan, 3 to 5 hours meeting we are ready. But our input it was not too high, but we are good in the process. Because our process were good, although it were derived from inputs 34-36 average score, we can achieved 37 score. Our graduation process is not inferior to the others, in the past we was 3 ranks in Bantul, but last year Science, Mathematics we are the Best!"

c. Development effort: Empowerment and learning community

The school has several programs to increase teacher's competencies. First is a classroom action research program. The school principal encourages teachers to conduct classroom action research in order to improve teaching and learning. Principal said that, "Not many teacher doing research, but we encourage and pushed them, we have been allocating budget for teacher research and gave the prize, it was Rp.1.5 million as a prize" (KS-3).

Principal deliver professional development of teachers. He focused on MGMP (teacher clubs). The teachers could share experiences, knowledge and information among them in the MGMP forum. Teacher of student year 10 also may understand the material required for student year 12 (T2-5).

Principal expects refreshment of teacher's competencies not only from formal activities, but personal activities e.g. reading activities. "Schools have subscribed the newspaper, magazines and tabloids, teachers also using Internet. In addition to the important information derived Principal presented to teachers in particular related to career and professional development" (KS-16). 
Principal briefing directly to the teachers does in every Monday (Obs-3). On the occasion, "the principal and teachers not only discuss topics that have prepared the principal but also things that are outside of the main topics. ... Coaching given to the team meetings quality improvement groups" (KS12). Meeting frequency can reach 2 to 3 times in a week. School established small groups among others, consists of religious guidance, school budgets, and extracurricular coaching (Obs -4).

Guidance for the development of careers teachers is also sought. Principal stated that position of Vice-Principal:

"A vice principal holds his/her position just for only three years, rotated to other teachers who are considered capable. Coaching staff at SMAN 1 Kasihan Bantul includes not only a profession but also a spiritual realm.

For a Moslem, spiritual development contained in recitals is held once a month at a school's mosque. Additionally Principal coordinate "infaq" (charity) movement monthly addressed to children less fortunate around the school" (WKS-9).

As for the students, the principal said efforts to build awareness and building awareness made in the following ways: "We socialize it when the flag ceremony, for example, Our Alumni's this year achieved the target, they exceeded $87 \%$ go to college, ... now we just preserving the quality, quality targets in ISO also been detailed in the quality guidelines of ISO and has been reached a target we raise the target every year"(WKS-6).

\section{DISCUSSION}

Awareness of the importance of school leadership climate in the school is a strategic belief that directs all its energy into developing the quality of the school. Leadership has a positive correlation to the effectiveness of the school. [8] Due to school climate that was developed by the school principal, the climate of the school is an integral part of the learning environment. [9] In addition, he also added that the school climate has a strategic contribution to the achievement of students. The basic principle of a school climate that established by the previous schools principal becoming frame of reference for the next leaders in running the school organization.

Principal of SMAN 1 Kasihan Bantul has a holistic view of quality schools, where it is not enough to focus only on output but also input and processes. From the academic dimension, the findings of this study indicate the issue of teachers as one of the trouble spots in teaching and learning improvement. Teacher should share information, skills and knowledge in order to improve the teaching and learning with their colleague. The high spirit teacher could make low quality students to be high quality students. This spirit is embodied in the performance of the teachers through the process output improvement.

High motivation in improving school quality would be success if accompanied with adequate competence. High spirits and competence must be possessed proficient. Cultivate the spirit of teachers can be started from lure of rewards for those who excel. Teachers should be internalized required competence to him/her. A good teacher is constantly improving his/her competence, well there is the lure of an award or not. Awards were not always all of matter. Selfactualization would be pushed to increase internal motivation. Teachers work comes with heart and competencies. SMAN 1 Kasihan Bantul still in early stages of providing financially rewards for teachers who improve their competence. In the future, the teachers should have been carrying out research and other profession activities for their own needs.

Learning community is used as a means of professional development of teachers in the form of teacher club/teacher forums (MGMP). In this forum collegial, teacher shares experiences, knowledge and information. The development is focused on aspects of the field of study of all levels in the education unit. Principal encourage all teachers to be active in learning community. It is parallel that principals have a significant role in establishing community learning in school. [10]

Supervision by the principal to the teachers carried out directly or indirectly. Directly mean is performed by the principal himself, while indirectly by delegation of authority to a competent teacher. Researchers looked at the pattern of coaching Principal of SMAN 1 Kasihan Bantul implement peer guidance. Peer guidance further intensified through MGMP and academic supervision. Supervision may help teacher to solve the problems/obstacles they met. Supervision help teacher to find out the shortcomings and advantages of their teaching performance in the classroom. Meanwhile, supervision also helps teacher to improve teaching and learning to be more effective to enhance student's understanding. Finally, supervision can also be used as guidance for teaching and learning improvement by school supervisors.

\section{ACKNOWLEDGMENT}

This project was made possible with funding from Faculty of Education Yogyakarta State University.

\section{REFERENCES}

[1] Githa, I.W. (2005). "Kontribusi Iklim Sekolah, Konsep Diri danMotivasi Berprestasi terhadap Prestasi Belajar Perawatan Kesehatan Masyarakat". Jurnal Pendidikan dan Pengajaran Ikip Negeri Singaraja, No. 4 Th. Xxxviii Oktober 2005.

[2] De Roche, Edward F. (1985). How School Administrators Solve Problems. New Jersey: Prentice Hall.

[3] Loukas, Alexandra. (2007). "What is School Climate? High-Quality School Climate is Advantageous for All Students and May be Particularly Beneficial for at-risk students". NAESP Leadership Compass Vol 5 no 1 Fall 2007.

[4] Kilpatrick, Sue \& Margaret, Barret \& Jones, Tammy. (2003). "Defining Learning Communities”. Discussion Paper D1/2003 CRLRA, University of Tasmania.

[5] Miller, Quennise \& William Allan Kritsonis. (2009). “A Conceptual Framework in Professional Learning Communities as They Impact Strategiec Planning in education". http://www.articlesbase.com/college-and-university-articles/aconceptual-framework-in-professional-learning-communities-as-theyimpact-strategic-planning-in-education-by-queinnise-miller-wmkritsonis-phd-1394976.html.

[6] Sergiovani. (2006). The Principalship; a Reflective Practice Perspective. Boston: Pearson. 
[7] Halawah, Ibtesam. 2005. "The Relationship Between Effective Communication of High School Principal and School Climate". Journal of Education, Winter 2005, p. 334-345.

[8] Deeboonmee, W. \& Ariratana, W. Relationship between Strategic Leadership and School Effectiveness. International Conference on Education \& Educational Psychology 2013 (ICEEPSY 2013). Procedia Social and Behavioral Sciences, Volume 112, 7 February 2014, Pages 982-985

[9] Maxwell, L.E., School building condition, social climate, student attendanceand academic achievement: A mediation model, Journal of Environmental Psychology, Volume 46, June 2016, Pages 206-216
[10] Balyer, A. Karatas, H., \& Alci, B. School Principals' Roles in Establishing Collaborative Professional Learning Communities at Schools. Procedia - Social and Behavioral Sciences, Volume 197, 25 July 2015, Pages 1340-1347

[11] Veloo,A. Komuji, M.M A, and Khalid,R.The effects of clinical supervision on the teaching performance of secondary school teachers. 3rd World Conference on Learning, Teaching and Educational Leadership. Procedia - Social and Behavioral Sciences, Volume 93, 21 October 2013, Pages 35-39 